\title{
PENGEMBANGAN MULTIMEDIA INTERAKTIF PEMBELAJARAN MATA KULIAH AKUNTANSI DASAR 1
}

Oleb:

\author{
B. Indab Nugrabeni
}

\begin{abstract}
Abstrak
Penelitian ini bertujuan mengungkapkan tahapan-tahapan dalam mengembangkan multimedia pembelajaran untuk mata kuliah Akuntansi Dasar 1 dengan karakteristik: (1) interaktif; (2) mencakup berbagai komponen media yaitu teks, gambar, animasi, suara, dan video; dan (3) dilengkapi lembar kerja mahasiswa.

Penelitian dan pengembangan (research and development) ini dilakukan lima tahap, yaitu: analisis kebutuhan, desain, produksi, evaluasi, dan revisi. Pada tahap produksi awal dievaluasi oleh ahli materi, ahli media, dan dosen mata kuliah Akuntansi Dasar 1. Ujicoba ada tiga tahap, yaitu oleh individu, kelompok kecil, dan uji coba lapangan. Subjek uji coba produk adalah mahasiswa Program Studi Pendidikan Akuntansi. Data berupa hasil penilaian mengenai kualitas produk, saran untuk perbaikan produk, skor tes, serta data kualitatif lainnya dikumpulkan melalui kuesioner, wawancara, tes, dan observasi.. Data kuantitatif dianalisis dengan statistik deskriptif dan inferensial. Saran-saran yang diperoleh digunakan sebagai dasar untuk merevisi produk.

Mahasiswa berpendapat bahwa multimedia yang dikembangkan berkualitas baik. Aspek pembelajaran memiliki rerata skor 4,17 (baik), aspek isi 4,16 (baik) dan aspek media 4,04 (baik). Rerata skor secara keseluruhan sebesar 4,12 yang termasuk dalam kriteria baik. Dari tes yang dilaksanakan diperoleh rerata skor pre-test sebesar 58,98 dan rerata skor post-test sebesar 79,65 , jadi ada kenaikan rerata skor sebesar 20,67 atau sebesar $35 \%$. Hasil uji $t$ menunjukkan bahwa kenaikan rerata skor signifikan. Jadi, dapat disimpulkan bahwa produk multimedia yang dikembangkan efektif untuk digunakan dalam proses pembelajaran Akuntansi Dasar 1.
\end{abstract}

Kata kunci: pengembangan multimedia interaktif, pembelajaran, akuntansi dasar 
Pengembangan Multimedia Interaktif Pembelajaran Mata Kuliab Akuntansi Dasar 1

\section{Pendahuluan}

Mata kuliah Akuntansi Dasar 1, diberikan pada semester pertama pada Program studi Pendidikan Akuntansi di Fakultas Keguruan dan Ilmu Pendidikan (FKIP) pada mahasiswa Jurusan Akuntansi pada Fakultas Ekonomi (FE). Mata kuliah ini berisi materi tentang konsep dasar akuntansi, siklus akuntansi pada perusahaan jasa dan perusahaan dagang. Sebagai mata kuliah diajarkan pada semester pertama, mata kuliah ini memegang peranan penting dan menentukan dalam mengantarkan para mahasiswa yang akan mempelajari materi akuntansi pada semester berikutnya.

Mata kuliah ini dimaksudkan untuk memberikan pengetahuan dasar kepada para mahasiswa. Oleh karena itu, bangunan pengetahuan akuntansi yang dimiliki mahasiswa akan banyak dipengaruhi oleh keberhasilan pembelajaran mata kuliah ini (Haryono Yusuf, 1998: 125). Mengingat pentingnya mata kuliah ini bagi mahasiswa, maka pembelajaran mata kuliah ini memerlukan pendekatan yang tepat dan strategik dalam memahamkan pengetahuan akuntansi kepada pemula sehingga salah persepsi dan sikap negatif terhadap akuntansi dapat dihindari (Suwardjono, 1999: 72).

Mengenalkan pengetahuan akuntansi kepada para mahasiswa di semester pertama bukanlah pekerjaan yang mudah. Kesalahan strategi dan pendekatan pengenalan dapat menimbulkan perilaku dan persepsi yang tidak diharapkan terhadap akuntansi. Beberapa kenyataan berikut dapat dijadikan indikator bahwa strategi dan pendekatan pengenalan akuntansi di tingkat pengantar mungkin kurang tepat (Suwardjono, 1999: 73-74), yaitu: (1) mahasiswa kurang mampu mengungkapkan konsep yang melandasi akuntansi dan hanya menguasai pengetahuan teknis; (2) mahasiswa mengartikan akuntansi dalam konteks yang sempit, yaitu hanya pada aspek teknis dan prosedural; (3) mahasiswa kurang mampu mengkaitkan mata kuliah akuntansi yang satu dengan mata kuliah akuntansi lainnya dalam suatu kerangka yang utuh dan menyeluruh yang membentuk disiplin akuntansi; (4). proses belajar akuntansi dasar lebih banyak membahas masalah 'bagaimana' tetapi kurang menekankan aspek 'mengapa'. 
Kesulitan mahasiswa dalam memahami materi akuntansi dasar kemungkinan juga disebabkan oleh metode pembelajaran konvensional yang digunakan selama ini, yaitu pembelajaran klasikal di kelas dengan menggunakan metode ceramah dan latihan soal. Proses pembelajaran juga masih didominasi dengan transfer pengetahuan dari dosen ke mahasiswa dan sumber belajar hanya berupa buku teks serta sumber belajar lainnya belum banyak dimanfaatkan. Demikian juga penggunaan media masih terbatas sehingga pembelajaran cenderung monoton dan kurang menarik. Metode pembelajaran konvensional tidak memungkinkan mahasiswa memperoleh pengalaman nyata, yang bersifat kontekstual, berkaitan dengan materi yang dipelajarinya. Selain itu, mahasiswa juga kurang dapat menghubungkan antara teori yang dipelajari dengan praktik yang terjadi di lapangan.

Kesulitan yang dialami para mahasiswa membuat mereka kurang termotivasi untuk mempelajarinya. Rendahnya motivasi ini juga berpengaruh terhadap strategi belajar yang mereka lakukan. Ada beberapa penyimpangan yang terjadi pada proses dan perilaku belajar mahasiswa, mengakibatkan prestasi yang dicapai tidak optimal. Perilaku belajar tersebut antara lain kegiatan belajar hanya terjadi di kelas dan hanya mengandalkan catatan, dosen tidak ada persiapan sebelum masuk kelas, mahasiswa tidak mengerjakan tugas/pekerjaan rumah yang diberikan, serta kemauan untuk berusaha yang rendah.

Serangkaian permasalahan belajar yang dihadapi mahasiswa tersebut perlu diatasi agar pembelajaran menjadi lebih efektif. Apabila mahasiswa merasakan kemudahan dalam belajar, maka motivasi belajarnya pun akan meningkat dan strategi belajarnya juga akan menjadi lebih baik. Untuk mencapai tujuan tersebut, perlu adanya perubahan terhadap metode pembelajaran yang selama ini berlangsung, antara lain dengan penggunaan media pembelajaran. Media pembelajaran yang saat ini banyak dimanfaatkan untuk membantu mengatasi berbagai masalah belajar adalah komputer multimedia. Komputer memiliki potensi yang cukup besar untuk dapat meningkatkan efektifitas proses pembelajaran, namun sampai saat ini belum banyak lembaga pendidikan yang memanfaatkan komputer untuk meningkatkan kualitas pembelajaran. Sementara itu, dari berbagai studi 
menunjukkan bahwa program pembelajaran yang dirancang dengan menggunakan komputer multimedia lebih efektif dibandingkan dengan paket pengajaran lainnya.

Berbagai permasalahan tersebut di atas, mendorong peneliti untuk mengembangkan multimedia interaktif untuk pembelajaran akuntansi, khususnya untuk materi mata kuliah Akuntansi Dasar 1. Untuk itu, upaya yang akan dilakukan dalam penelitian ini adalah: bagaimana mengembangkan multimedia interaktif yang efektif digunakan untuk pembelajaran mata kuliah Akuntansi Dasar 1 bagi para mahasiswa Prodi PAk, FKIP, Universitas Sanata Dharma (USD) Yogyakarta.

Penelitian ini bertujuan untuk mengungkap tahapan - tahapan dalam mengembangkan multimedia pembelajaran dẹngan efektif untuk pembelajaran mata kuliah Akuntansi Dasar 1. Multimedia diharapkan memiliki karakteristik antara lain: (1) bersifat interaktif; (2) mencakup berbagai komponen media yaitu teks, gambar, animasi, suara, dan video; dan (3) memberikan fasilitas kepada mahasiswa untuk aktif selama proses pembelajaran, dengan tersedianya lembar kerja dan software multimedia.

Hasil penelitian ini akan memberi mamfaat bagi: (1) mahasiswa Prodi PAk untuk membantu mereka dalam proses pembelajaran mata kuliah Akuntansi Dasar 1; (2) dosen pengampu mata kuliah Akuntansi Dasar 1, untuk dimanfaatkan dalam proses pembelajaran mata kuliah Akuntansi Dasar I khususnya untuk pokok bahasan Siklus Akuntansi Perusahaan Jasa; (3) lembaga, khususnya Prodi PAk, USD, mengingat belum ada pengembangan multimedia untuk pembelajaran mata kuliah ini.

\section{Konsep Multimedia Interaktif}

Istilah multimedia berasal dari kata 'multi' dan 'media' yang kemudian membentuk satu kata 'multimedia'. Namun, sering dijumpai kata 'multimedia' dan frasa 'multi media', keduanya memiliki pengertian berbeda, meskipun keduanya melibatkan semua jenis media yaitu teks, gambar, animasi, suara, dan film atau video. Menurut Sabatini (Hardhono, 2005), pada frasa multi media, komponen-komponen media tersebut berdiri sendiri, yaitu teks dan gambar disajikan dalam bahan tercetak atau 
slide, suara disajikan dalam bentuk kaset audio, animasi dan film/video disajikan dalam kaset video atau compact disk $(C D)$. Sedangkan pada kata multimedia, semua komponen media yaitu: teks, gambar, animasi, suara, dan film atau video disajikan dalam suatu alat, yaitu komputer multimedia.

Definisi di atas senada dengan pernyataan Borsook dan Higginbotham-Wheat (Steffey, 2001: 9), yaitu:

...it would be easy to remember that multimedia stands for multiple media except that the term media can mean many tbings. Media' can include slides, audio tapes, videotapes, video conferencing, animations, film, music, voice, paper, or even someone shouting through a megaphone. Media can be instructional or not, it can be interactive or not, and it can be computer-based or not.

Dari berbagai literatur, istilah multimedia dan multimedia interaktif didefinisikan dengan rumusan yang hampir sama, antara lain pernyataan Timothy Newby (2000: 101) berikut ini:

The term multimedia conveys the notion of a system in which various media (e.g., text, graphics, video, and audio) are integrated into a single delivery system under computer control. A modern interactive multimedia system may weave together text, graphics, animation, data, video, and audio from various sources, including a videodisc, $a C D$, and the computer it self.

Gayeski D.M (Villamil \& Molina, 1997: 6) memberikan penjelasan mengenai multimedia dan multimedia interaktif, sebagai berikut :

The word multimedia refers to the integration of multiple media-such as visual imagery, text, video, sound, and animation-which together can multiply the impact of the message. Some authors prefer to define it as a class of computerdriven interactive communication systems that create, store, transmit, and retrieve textual, graphic, and auditory networks of information. On another level, interactive multimedia refers to the ability to control these components and interact with them as needed.

Multimedia banyak digunakan di berbagai bidang pekerjaan. Multimedia yang dimanfaatkan dalam bidang pendidikan khususnya dalam kegiatan pembelajaran disebut dengan multimedia pembelajaran, dengan memanfaatkan teknologi komputer. 
Pentingnya Multimedia dalam Pembelajaran

Setiap komponen media dapat merangsang satu atau lebih indra manusia. Teori Koehnert (Hardhono, 2005) mengatakan bahwa semakin banyak indra yang terlibat dalam proses belajar, maka proses belajar tersebut akan menjadi lebih efektif. Secara tegas teori ini menyarankan penggunaan lebih dari satu indera manusia. Oleh karena itu, pemanfaatan multimedia dalam pembelajaran dapat diharapkan meningkatkan hasil belajar.

Pernyataan di atas berkaitan dengan pendapat Dale yang menyatakan bahwa pemerolehan hasil belajar melalui indra pandang berkisar $75 \%$, melalui indra dengar sekitar $13 \%$, dan melalui indra lainnya sekitar $12 \%$. Hal senada ditegaskan oleh Baugh (1986) yang menyatakan bahwa kurang lebih $90 \%$ hasil belajar seseorang diperoleh melalui indra pandang, 5\% diperoleh melalui indra dengar, dan $5 \%$ lagi diperoleh melalui indra lainnya. Hasil penelitian yang dilakukan British Audio Visual Aids (BAVA) tahun 1988 menunjukkan bahwa informasi yang diserap melalui indra pendengaran hanya $13 \%$ saja, sedangkan $87 \%$ melalui indra yang lainnya (Depdiknas, 2004: 3-4; Azhar Arsyad, 2005: 10).

Selain itu multimedia juga fleksibel dalam menyesuaikan dengan kecepatan belajar seseorang dan lebih fleksibel berkaitan dengan waktu dan tempat. Pembelajaran dengan menggunakan multimedia juga memberikan beberapa keuntungan. Townsend \& Townsend (Snyder, 1996: 179) menyatakan bahwa multimedia memiliki enam keuntungan, yaitu:

a. multimedia reaches the senses, which enbances learning as it can be tailored to the learning style of individuals;

b. multimedia encourages and validates individual self expression by allowing students to decide bow they assimilate information;

c. multimedia gives a sense of ownership as individual students actually create what they learn;

d. multimedia creates an active, not passive, atmosphere for learning, which forces students into participation and interaction with presented material;

e. multimedia acts as a catalyst for communication between students and between students and instructors; 
f. the use of multimedia is already witbin the day to day environment of most individuals from automatic bank tellers, to video games and television and most individuals can relate to the technology.

\section{Metode Penelitian}

Jenis penelitian ini adalah penelitian dan pengembangan atau research and development $(R \circlearrowleft D)$. Penelitian dan pengembangan produk multimedia ini mengadopsi langkah-langkah yang dikemukakan Borg and Gall (1983: 775). Langkah-langkah tersebut dilengkapi dengan langkah-langkah penelitian dan pengembangan yang dikemukakan oleh Wasis $\mathrm{D}$. Dwiyogo (2004: 7-8). Sedangkan pengembangan multimedia menggunakan langkahlangkah yang dikemukakan oleh Eleanor L. Criswell (1989: 50-81), Arif S. Sadiman, et al. (2003:97-180), dan Luther (Ariesto Hadi Sutopo: 2003:3248). Sementara itu, pengembangan program pembelajaran menggunakan model pengembangan pembelajaran dari Reigeluth (1983: 18-19). Prosedur pengembangan tersebut tampak dalam diagram berikut ini. 
Pengembangan Multimedia Interaktif Pembelajaran Mata Kuliab Akuntansi Dasar 1

I

Analisis Kebutuhan untuk Menentukan Mata Kuliah

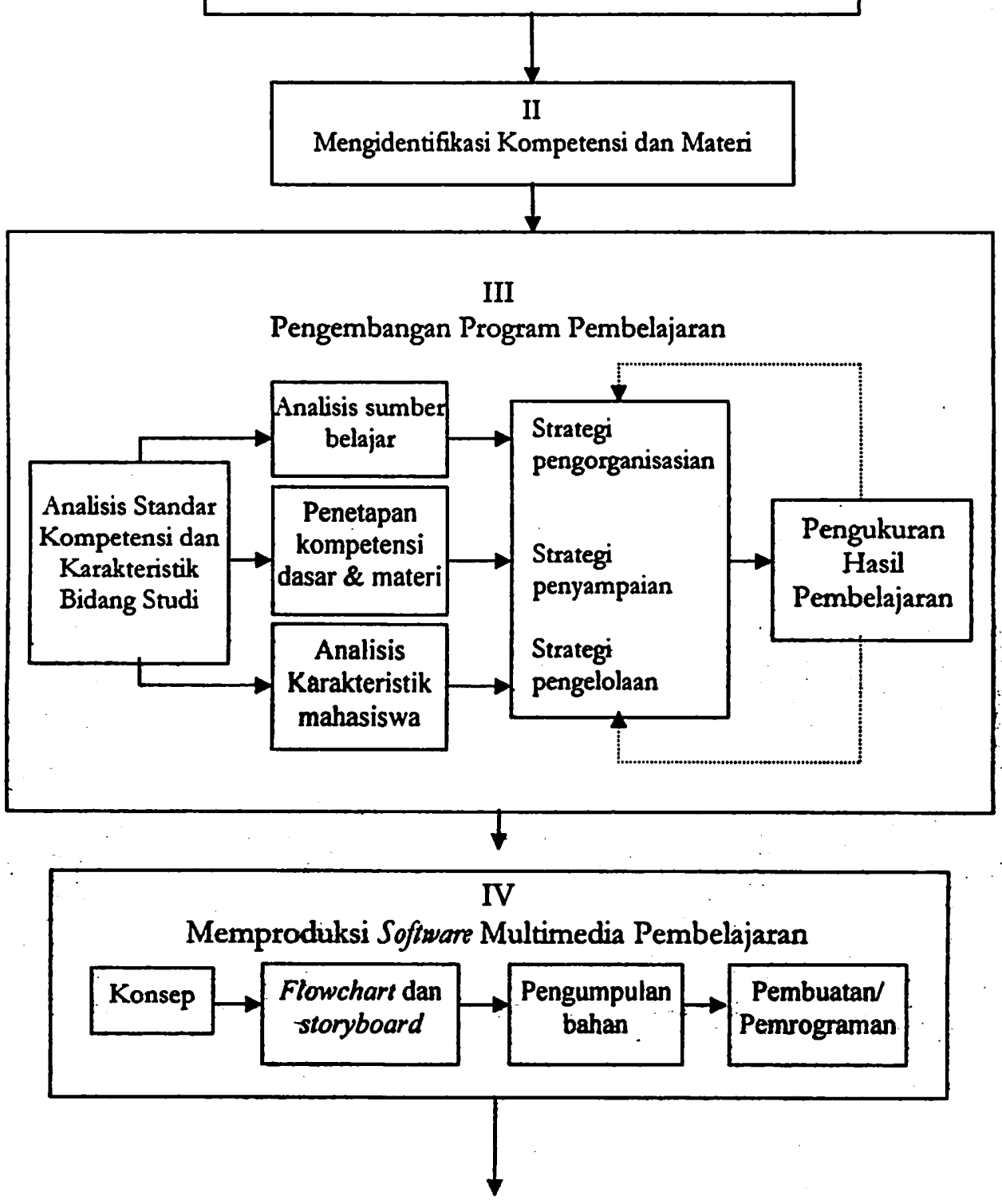




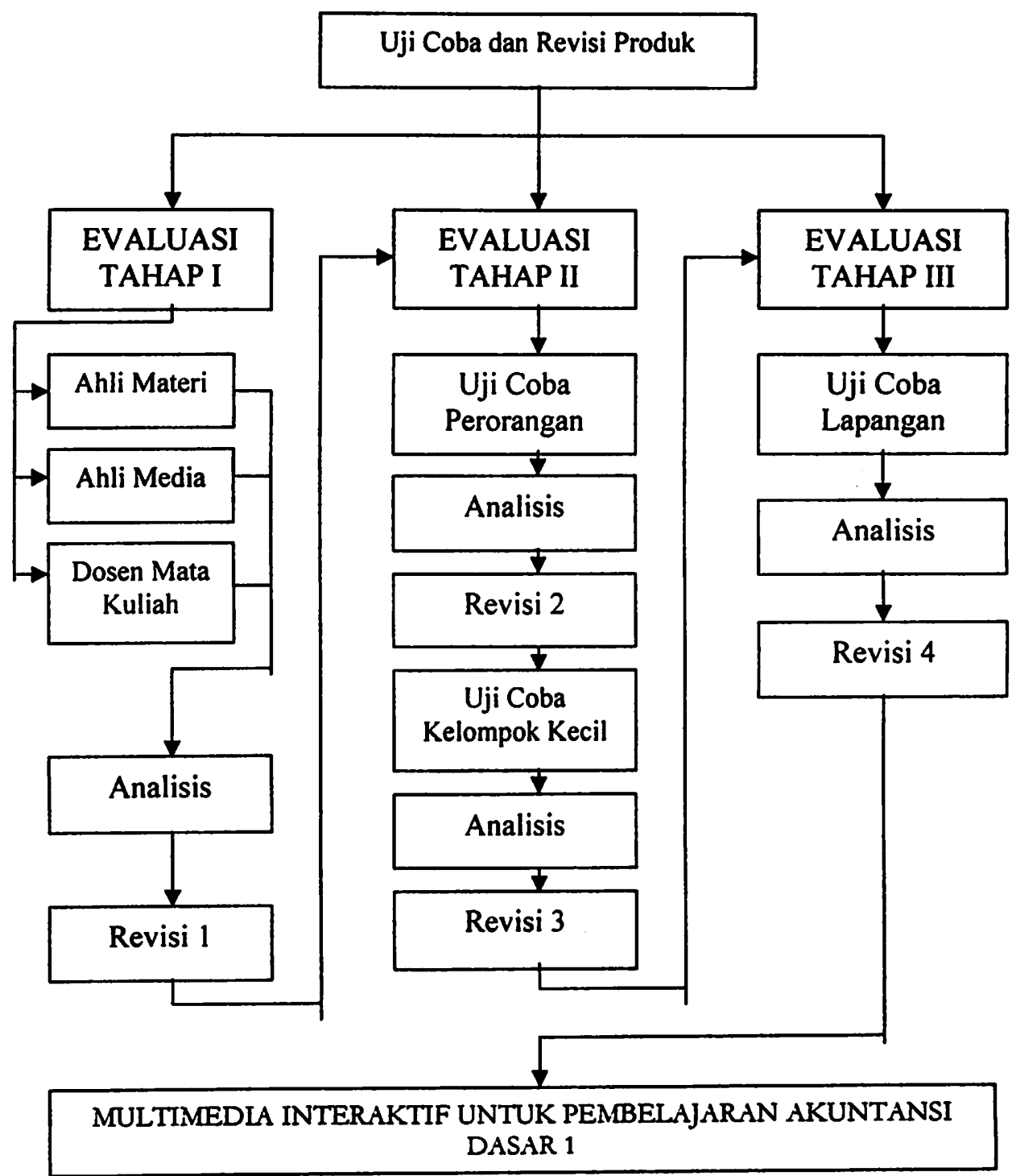

Gambar 1. Prosedur Pengembangan Multimedia Pembelajaran Mata Kuliah Akuntansi Dasar 1 
Subjek uji coba atau responden untuk uji coba produk adalah mahasiswa Prodi PAk, FKIP, USD, Yogyakarta. Pada uji coba satu lawan satu terdiri dari 4 mahasiswa, uji coba kelompok kecil 12 mahasiswa, dan uji coba lapangan 37 mahasiswa. Subjek uji coba ditentukan melalui konsultasi dengan beberapa dosen, sehingga mencakup berbagai karakteristik, antara lain terdiri dari mahasiswa yang memiliki kemampuan kurang baik, sedang, dan baik; dan terdiri dari mahasiswa berjenis kelamin laki-laki dan perempuan dengan jumlah yang proporsional.

Instrumen yang digunakan untuk mengumpulkan data pada penelitian ini berupa kuesioner dan tes akuntansi dasar. Instrumen berupa kuesioner digunakan untuk mengevaluasi kualitas multimedia dan instrumen berupa tes akuntansi dasar disusun untuk mengetahui efektifitas multimedia dalam proses pembelajaran. Kuesioner untuk ahli materi dan dosen mata kuliah berisi buku-buku untuk menilai kualitas multimedia pada aspek pembelajaran dan aspek isi/materi. Kuesioner untuk ahli media berisi buku-buku untuk menilai kualitas multimedia pada aspek tampilan, penyajian, dan pemrograman. Sedangkan untuk mahasiswa berisi butirbutir untuk menilai multimedia pada aspek pembelajaran, isi/materi, dan media. Tes akuntansi dasar digunakan untuk memperoleh skor pre-test dan post-test pada uji coba lapangan. Pengembangan instrumen pengumpul data dilakukan melalui dua tahapan, yaitu penyusunan instrumen dan uji coba instrumen.

Data yang diperoleh melalui kegiatan uji coba diklasifikasikan menjadi dua, yaitu data kualitatif dan data kuantitatif. Data kualitatif yang berupa kritik dan saran dari ahli media, ahli materi, dosen mata kuliah, dan mahasiswa dihimpun dan disarikan untuk memperbaiki produk multimedia pembelajaran ini.

Data kuantitatif mengenai kualitas multimedia yang diperoleh dari para responden melalui kuesioner dengan skala Likert dianalisis secara statistik deskriptif. Penilaian kualitas multimedia didasarkan pada hasil perhitungan konversi nilai dengan skala lima sebagai berikut (Sukardjo, 2005: 53): 
Tabel 1

Hasil Perhitungan Konversi Nilai dengan Skala Lima

\begin{tabular}{|l|c|}
\hline \multicolumn{1}{c|}{ Kategori } & Interval Skor \\
\hline Sangat Baik & $\mathrm{X}>4,21$ \\
\hline Baik & $3,40<\mathrm{X} \leq 4,21$ \\
\hline Cukup Baik & $2,60<\mathrm{X} \leq 3,40$ \\
\hline Kurang Baik & $1,79<\mathrm{X} \leq 2,60$ \\
\hline Sangat Kurang Baik & $\mathrm{X} \leq 1,79$ \\
\hline
\end{tabular}

Data yang diperoleh dari pre-test dan post-test dianalisis menggunakan uji $t$ untuk melihat perbedaan mean antara skor pre-test dan post-test.

\section{Hasil Penelitian dan Pengembangan}

Proses pengembangan multimedia interaktif untuk pembelajaran Akuntansi Dasar 1 ini secara garis besar melalui beberapa tahap, yaitu analisis kebutuhan, desain, produksi, evaluasi, dan revisi.

Pada proses desain ditentukan tujuan, sasaran, materi, dan dilanjutkan dengan membuat flowchart dan storyboard. Pada tahap produksi semua bahan yang berupa teks, gambar, suara, animasi, maupun video disusun dengan menggunakan program Macromedia Flash 8 dan dibantu dengan program Photoshop CS2, Sound Forge 7, dan U Lead Studio Video 8. Hasil dari tahap produksi berupa produk awal yang selanjutnya dievaluasi melalui beberapa tahap, yaitu evaluasi ahli materi dan dosen mata kuliah Akuntansi Dasar 1, ahli media, uji coba satu lawan satu, uji coba kelompok kecil dan uji coba lapangan.

Hasil validasi produk oleh ahli materi dan dosen mata kuliah Akuntansi Dasar 1 menunjukkan bahwa multimedia memiliki kualitas baik. Skor yang diberikan oleh kedua ahli materi dan dosen mata kuliah untuk aspek pembelajaran dan aspek isi secara lebih jelas dapat dilihat pada tabel berikut ini. 
Pengembangan Multimedia Interaktif Pembelajaran Mata Kuliah Akuntansi Dasar 1

\section{Tabel 2}

Kualitas Produk Multimedia Hasil Validasi Ahli Materi dan Dosen Mata Kuliah Akuntansi Dasar 1

\begin{tabular}{|c|c|c|c|c|c|}
\hline \multirow{2}{*}{ Aspek Penilaian } & \multicolumn{4}{|c|}{ Rerata Skor } & \multirow{2}{*}{ Kriteria } \\
\cline { 2 - 6 } & $\begin{array}{c}\text { Ahli } \\
\text { Materi I }\end{array}$ & $\begin{array}{c}\text { Ahli } \\
\text { Materi II }\end{array}$ & $\begin{array}{c}\text { Dosen } \\
\text { MR }\end{array}$ & Rerata & \\
\hline Aspek Pembelajaran & 4,07 & 4,03 & 4,03 & 4,04 & Baik \\
\hline Aspek Isi/Materi & 4,13 & 4,31 & 4,25 & 4,23 & Sangat baik \\
\hline Rerata & 4,10 & 4,17 & 4,14 & 4,14 & Baik \\
\hline
\end{tabular}

Hasil validasi produk oleh ahli media menunjukkan bahwa kualitas produk dilihat dari aspek tampilan dan aspek pemrograman dinyatakan sangat baik. Sedangkan aspek penyajian, masuk dalam kriteria baik. Skor yang diberikan oleh kedua ahli media untuk ketiga aspek tersebut dapat dilihat pada tabel berikut ini.

Tabel 3

Kualitas Produk Multimedia Hasil Validasi Ahli Media

\begin{tabular}{|l|c|c|c|c|}
\hline \multirow{2}{*}{ Aspek Penilaian } & \multicolumn{3}{|c|}{ Rerata Skor } & \multirow{2}{*}{ Kriteria } \\
\cline { 2 - 4 } & $\begin{array}{c}\text { Ahli } \\
\text { Media I }\end{array}$ & $\begin{array}{c}\text { Ahli } \\
\text { Media II }\end{array}$ & Rerata & \\
\hline Aspek Tampilan & 4,30 & 4,95 & 4,63 & Sangat baik \\
\hline Aspek Penyajian & 4,14 & 4,00 & 4,07 & Baik \\
\hline Aspek Pemrograman & 4,20 & 4,89 & 4,55 & Sangat baik \\
\hline Rerata & 4,21 & 4,61 & 4,41 & Sangat baik \\
\hline
\end{tabular}

Hasil uji coba produk kepada mahasiswa ditunjukkan pada tabel berkut ini. 
Tabel 4

Kualitas Produk Multimedia Hasil Uji Coba

\begin{tabular}{|l|l|c|c|}
\hline $\begin{array}{l}\text { Tahap Uji } \\
\text { Coba }\end{array}$ & $\begin{array}{l}\text { Aspek } \\
\text { Penilaian }\end{array}$ & Rerata Skor & Kategori \\
\hline \multirow{4}{*}{$\begin{array}{l}\text { Satu Lawan } \\
\text { Satu }\end{array}$} & Pembelajaran & 3,90 & Baik \\
\cline { 2 - 4 } & Isi/Materi & 3,89 & Baik \\
\cline { 2 - 4 } & Media & 3,79 & Baik \\
\cline { 2 - 4 } & Rerata & 3,86 & Baik \\
\hline \multirow{4}{*}{ Kelompok } & Pembelajaran & 4,20 & Baik \\
\cline { 2 - 4 } & Isi/Materi & 4,23 & Sangat Baik \\
\cline { 2 - 4 } & Media & 4,02 & Baik \\
\cline { 2 - 4 } & Rerata & 4,15 & Baik \\
\hline \multirow{5}{*}{ Lapangan } & Pembelajaran & 4,17 & Baik \\
\cline { 2 - 4 } & Isi/Materi & 4,16 & Baik \\
\cline { 2 - 4 } & Media & 4,04 & Baik \\
\cline { 2 - 4 } & Rerata & 4,12 & Baik \\
\hline
\end{tabular}

Proses revisi produk dilakukan berdasarkan masukan dari para ahli dan mahasiswa. Revisi dari ahli materi I dan II sebanyak 20 macam revisi; dari dosen mata kuliah Akuntansi Dasar 1 sebanyak 8 revisi; dari ahli media I dan II sebanyak 21 revisi; dari uji coba satu lawan satu sebanyak 3 revisi; dari uji coba kelompok kecil sebanyak 4 revisi; dan dari uji coba lapangan sebanyak 3 revisi. Revisi antara lain berkaitan dengan: koreksi isi materi, penambahan materi, kesalahan ejaan, penambahan narasi, perbaikan struktur navigasi, dan kelengkapan informasi dalam setiap tampilan. 
Untuk mengetahui efektifitas multimedia pembelajaran akuntansi ini, dalam uji coba lapangan diselenggarakan pre-test dan post-test. Deskripsa data dan distribusi frekuensi skor pre-test dan post-test dari uji coba lapangan adalah sebagai berikut:

Tabel 5

Deskripsi Data Skor Pre-Test dan Post-Test dari Uji Coba Lapangan

\begin{tabular}{|c|c|c|c|}
\hline Keterangan & Pre-Test & Post-Test & Selisih \\
\hline Maksimum & 92,80 & 97,90 & 5,1 \\
\hline Minimum & 37,90 & 59,30 & 21,4 \\
\hline Range & 54,90 & 38,60 & 16,3 \\
\hline Rerata (mean) & 58,98 & 79,65 & 20,67 \\
\hline Standar Deviasi & 14,53 & 12,45 & 2,08 \\
\hline Modus & 43,90 & 67,90 & 24 \\
\hline Median & 56,50 & 80,30 & 23,8 \\
\hline
\end{tabular}

Tabel 6

Distribusi Frekuensi Skor Pre-Test dan Post-Test dari Uji Coba Lapangan

\begin{tabular}{|c|c|c|c|}
\hline Range Skor & Nilai & \multicolumn{2}{|c|}{ Frekuensi } \\
\cline { 3 - 4 } & & Pre-Test & Post-Test \\
\hline $80-100$ & A & 5 & 19 \\
\hline $66-79$ & B & 5 & 12 \\
\hline $56-65$ & C & 11 & 6 \\
\hline $50-55$ & D & 1 & 0 \\
\hline $0-49$ & E & 15 & 0 \\
\hline r vonith & & 37 & 37 \\
\hline
\end{tabular}


Agar dapat diambil kesimpulan apakah terjadi peningkatan yang signifikan dari skor pre-test ke skor post-test, maka dilakukan analisis statistik uji beda mean dengan menggunakan uji $t$ untuk sampel berpasangan. Dari output uji $t$ diketahui bahwa: (1) rerata skor pre-test sebesar 58.98 dan posttest sebesar 79,65; (2) terdapat korelasi yang erat antara skor pre-test dan posttest karena koefisien korelasinya sebesar 0,853 dengan nilai probabilitas jauh di bawah 0,05 , yaitu 0,00 ; (3) nilai probabilitas pada uji beda mean sebesar 0,00 , lebih kecil dari 0,05 . Jadi dapat disimpulkan bahwa rerata skor pre-test dan post-test berbeda secara signifikan. Dengan kata lain, terjadi peningkatan yang singnifikan dari skor tes sebelum belajar menggunakan multimedia ke skor tes setelah belajar menggunakan multimedia.

Melalui wawancara dengan para mahasiswa, terungkap bahwa mereka memperoleh berbagai manfaat dan lebih termotivasi, serta tertarik dan senang belajar menggunakan multimedia ini. Mereka juga mengungkapkan bahwa mereka mudah memahami materi yang disajikan melalui multimedia. Dilihat dari lamanya waktu yang dibutuhkan untuk mempelajari materi yang disajikan melalui multimedia ini dapat dikatakan bahwa dengan menggunakan multimedia lebih efisien dibandingkan dengan pembelajaran dengan metode konvensional. Dari hasil observasi selama pelaksanaan uji coba juga terlihat bahwa para mahasiswa merasa senang dan antusias ketika belajar dengan multimedia ini. Mereka merasa tidak bosan karena dapat terlibat secara aktif dalam proses pembelajaran.

Secara umum produk ini memiliki beberapa kelebihan, antara lain: (1) memungkinkan mahasiswa belajar secara aktif dan mandiri; (2) mudah digunakan oleh pengguna; (3) membantu mahasiswa dalam mempelajari materi siklus akuntansi; (4) memiliki kualitas yang relatif baik dari berbagai aspek, yaitu aspek pembelajaran, isi, tampilan, penyajian, maupun pemrograman; (5) tidak membosankan karena materi disajikan dalam berbagai media.

Adapun kelemahan atau kekurangan produk ini, antara lain:

1. Beberapa tabel atau gambar, tidak bisa ditampilkan secara maksimal karena keterbatasan ruang sehingga tulisan dan angka pada tabel tersebut terlalu kecil. Demikian juga tampilan soal dan lembar kerja pada latihan tidak dapat ditampilkan secara bersamaan. 
2. Soal evaluasi yang terdiri dari soal pilihan ganda dan soal isian pendek kurang sesuai untuk mengukur kompetensi yang diharapkan dari materi siklus akuntansi. Bentuk soal yang lebih tepat adalah soal essay atau praktik dan mahasiswa mengerjakannya pada lembar kerja, seperti yang dilakukan untuk pre-test dan post-test pada uji coba lapangan. Namun apabila bentuk soal essay dimasukkan dalam produk akan muncul kesulitan dalam penghitungan skor.

3. Hasil pengisian lembar kerja oleh mahasiswa tidak dapat disimpan dalam file.

\section{Simpulan}

a. Pengembangan multimedia ini dilakukan dengan menggunakan langkahlangkah penelitian dan pengembangan yang dikemukakan oleh Borg and Gall, dan dikombinasikan dengan langkah-langkah dari Wasis D. Dwiyogo. Sedangkan untuk pengembangan program pembelajaran digunakan model pengembangan yang dikemukakan oleh Charles $M$. Reigeluth. $\mathrm{Di}$ samping itu, untuk pengembangan multimedia menggunakan langkah-langkah pengembangan media yang dikemukakan oleh Eleanor L. Criswell, Arif S. Sadiman, et al., dan Luther. Dengan menggunakan langkah-langkah penelitian dan pengembangan, model pengembangan program pembelajaran, dan langkah-langkah pengembangan media, dari beberapa ahli di atas, dapat dihasilkan multimedia pembelajaran untuk mata kuliah Akuntansi Dasar 1 yang efektif dalam proses pembelajaran.

b. Penilaian mahasiswa pada uji coba lapangan, mengenai kualitas multimedia yang dikembangkan ini adalah baik. Sebanyak 43,24\% mahasiswa menilai aspek pembelajaran sangat baik, 54,06\% menilai baik, dan 2,70\% menilai cukup baik. Aspek isi dinilai sangat baik oleh $54,05 \%$, sementara itu $37,84 \%$ menilai baik, dan $8,11 \%$ menilai cukup baik. Sedangkan aspek media dinilai sangat baik oleh $40,54 \%$ mahasiswa, dinilai baik oleh 56,76\% mahasiswa dan 2,70\% mahasiswa menilai cukup baik. Dilihat dari besarnya rerata skor pada setiap aspek, aspek pembelajaran memiliki rerata skor 4,17 (baik), aspek isi 4,16 (baik) 
dan aspek media 4,04 (baik). Rerata skor secara keseluruhan sebesar 4,12 yang termasuk dalam kriteria baik. Selain itu, terungkap bahwa melalui multimedia mahasiswa dapat mempelajari materi siklus akuntansi dengan lebih mudah, lebih cepat, lebih aktif, tidak membosankan, lebih mandiri serta termotivasi dalam belajar.

c. Produk multimedia yang dikembangkan efektif untuk digunakan dalam proses pembelajaran Akuntansi Dasar 1. Hasil uji $t$ rerata skor disimpulkan bahwa rerata skor pre-test dan post-test berbeda signifikan.

\section{Keterbatasan}

a. Produk yang dihasilkan belum sempurna, misalnya dalam hal kelengkapan materi dan bentuk soal evaluasi yang kurang sesuai untuk mengukur kompetensi yang diharapkan untuk materi siklus akuntansi.

b. Proses uji coba untuk mengetahui efektifitas multimedia tidak menggunakan metode eksperimen dengan melibatkan kelompok kontrol yang mengalami proses pembelajaran tanpa menggunakan multimedia.

\section{Saran}

Berdasarkan kesimpulan dan keterbatasan di atas, dapat disarankan sebagai berikut: (a) perlu dilakukan penyempurnaan dan melakukan antisipasi untuk mengatasi kelemahan yang ada. Misalnya dengan melengkapi materi dan menyediakan soal evaluasi beserta lembar kerjanya di luar software ini; (b) perlu dilakukan penelitian lanjutan menggunakan metode eksperimen dengan melibatkan kelompok kontrol; (c) produk sebaiknya dimanfaatkan dalam proses pembelajaran pada mata kuliah Akuntansi Dasar 1. Pada tahap awal, produk ini dapat dimanfaatkan sebagai variasi metode pembelajaran atau sebagai pelengkap pembelajaran di kelas; (d) sebaiknya dilakukan pengembangan multimedia pada mata kuliah akuntansi yang lainnya agar proses pembelajaran dapat lebih efektif dan efisien, serta motivasi dan kemandirian belajar mahasiswa dapat ditingkatkan. 


\section{Pengembangan Multimedia Interaktif Pembelojaran Mata Kuliab Akuntansi Dasar 1}

\section{Daftar Pustaka}

Arif S. Sadiman, et al. (2003). Media pendidikan: Pengertian, pengembangan, dan pemanfaatannya. Jakarta: PT Raja Grafindo Persada.

Azhar Arsyad. (2005). Media pembelajaran. Jakarta: PT Raja Grafindo Persada.

Borg, W.R. dan Gall, M.D. (1983). Educational research: An introduction (4t ed.). New York: Longman.

Depdiknas. (2004). Pedoman merancang sumber belajar. Jakarta: Depdiknas.

Gay, L.R. (1990). Educational research: Competencies analysis and application (3 ${ }^{\text {nt }}$ ed.). Singapore: Macmillan Publishing Company.

Hardhono, A.P. Pengembangan baban ajar multimedia. Diambil pada tanggal 22 Oktober 2005, dari http://pk.ut.ac.id/pii /artikel/ AP\%20Hardhono a.pdf.

Haryono Yusuf. (1998). Beberapa catatan tentang pengajaran akuntansi pengantar. Jurnal Ekonomi dan Bisnis Indonesia. Vol. 13, No. 4, 125-137.

Newby, T.J., et al. (2000). Instructional technology for teaching and learning: Designing instruction, integrating computer, and using media. New Jersey: Prentice Hall, Inc.

Reigeluth, C. M. (Ed.). (1983). Instructional design theories and models: $A n$ overview of their current status. Lawrence Erlbaum Associates: N.J. USA.

Snyder,L.T. (1996). Multimedia \& learning: Where's the connection?. Developments In Business Simulation of Experiential Exercises, Volume 23. Diambil pada tanggal 23 Juni 2006, dari http://sbaweb.wayne.edu/ حabsel/bkl/vol.23/23bp.pdf.

Steffey, C. S. (2001). The effects of visual and verbal cues in multimedia instruction. Disertasi doctor, tidak diterbitkan, Virginia Polytechnic Institute and State University. 
Suwardjono. (1999). Memahamkan pengetahuan akuntansi di tingkat pengantar. Jumal Ekonomi dan Bisnis Indonesia. Vol. 14, No. 1, 71-87.

Villamil, J. \& Molina, L. (1997). Multimedia: Production, planning and delivery. USA: Que Education \& Training, Macmillan Computer Publishing.

Wasis D. Dwiyogo. (Juli 2004). Konsep penelitian dan pengembangan. Makalah disajikan dalam Seminar Lokakarya Nasional Metodologi Penelitian Pengembangan Bidang Pendidikan dan Pembelajaran, di Universitas Negeri Yogyakarta. 